ФІНАНСОВА СТІЙКІСТЬ ПІДПРИЕМСТВА ЯК ОСНОВНИЙ ПОКАЗНИК ФІНАНСОВОГО СТАНУ

\title{
FINANCIAL STABILITY OF THE ENTERPRISE AS THE MAIN INDICATOR OF FINANCIAL CONDITION
}

УдК 338.58:65.014

https://doi.org/10.32843/infrastruct38-34

\section{Старкіна М.о.}

студентка

Чернівецький національний університет імені Юрія Федьковича

Гаватюк Л.С.

к.е.н., викладач кафредри публічних, корпоративних фрінансів

та фрінансового посередництва

Чернівецький національний університет імені Юрія Федьковича

\begin{abstract}
Кожний суб'єкт господарювання зацікавлений у розвитку свого виробництва, підвищенні рівня конкурентоспроможності продукції і самого підприємства загалом. Для вирішення цього питання стане у пригоді аналіз фрінансової стійкості підприємства. У статті здійснено аналіз основних засад фрінансової стійкості підприємства. Розглянуто об'єктивну оцінку фрінансової стійкості підприємства як основу його життєздатності, яке $\epsilon$ важливим інфрормаційним джерелом для обірунтування і прийняття оптимального управлінського рішення щодо суб'єкта господарювання. Під час дослідження системності оцінювання фрінансової стійкості запропоновано аналітичні показники коефріцієнта фрінансової автономії, або незалежності, коесріцієнт маневреності власних коштів, коефіцієнт ефрективності. Наведено основні чинники, що впливають на зниження чи зростання фрінансової стійкості суб'єкта господарювання. Обгрунтовано ії основні складники та важливість позитивного впливу на результати фрункціонування підприємства.

Ключові слова: економіка, фрінансова стійкість, фінансові ресурси, капітал, підприємство, активи, виробництво
\end{abstract}

Каждый субъект хозяйствования заинтересован в развитии своего производства, повышении уровня конкурентоспособности продукции и самого предприятия в целом. Для решения этого вопроса пригодится анализ фринансовой устойчивости предприятия. В статье осуществлен анализ основных принципов фринансовой устойчивости предприятия. Рассмотрена объективная оценка фринансовой устойчивости предприятия как основа его жизнеспособности, которая является важным информационным источником для обоснования и принятия оптимального управленческого решения в отношении субъекта хозяйствования. Для исследования системности оценки фринансовой устойчивости предложены аналитические показатели коэфорициента фринансовой автономии, или независимости, коэффрициент маневренности собственных кошек, коэфрфициент эфрфективности. Приведены основные фракторы, влияющие на снижение или рост фринансовой устойчивости предприятия. Обоснованы ее основные составляющие и важность положительного влияния на результаты функционирования предприятия.

Ключевые слова: экономика, фринансовая устойчивость, фринансовые ресурсы, капитал, предприятие, активы, производство.

Every business entity is interested in developing its production, improving the competitiveness of its products and the enterprise itself. An analysis of the financial soundness of the enterprise will be helpful to address this issue. The article analyzes the basic principles of financial stability of an enterprise. Financial stability is a certain state of the accounts of an enterprise, which will guarantee its constant solvency. Sustainable production and good sales, increase profit over cost and effective cost the use of finance is the key to financial sustainability enterprises Financial stability characterizes the degree of financial independence of an enterprise in the possession and use of its property. An objective assessment of the financial soundness of an enterprise is considered as the basis of its viability, which is an important information source for substantiation and making the best management decision regarding an entity. In the study of the systematic evaluation of financial stability, analytical indicators of the coefficient of financial autonomy or independence, the coefficient of maneuverability of own cats, the coefficient of efficiency are offered. Financial soundness indicators - show the level of borrowing capital and the ability of the company to service this debt. Financial ratios should be informative and should give a complete picture of the financial stability of the enterprise; for all financial ratios the minimum satisfactory level or range of change should be specified. The main factors that influence the decrease or increase in the financial stability of the entity. Its main components and the importance of positive influence on the results of functioning of the enterprise are substantiated. significant influence on the enterprise and its financial stability are affected by economic and political processes in the country, technological development, consumer solvency, competition. The financial sustainability of an enterprise implies that resources invested in business activities must be paid for by cash income, and the profit generated should ensure self-financing and independence of the enterprise from external sources of asset formation.

Key words: economy, financial stability, financial resources, capital, enterprise, assets, production.

Постановка проблеми. У ринкових умовах фрінансова стійкість служить заставою виживання та основою стабільного стану підприємства фрінансових засобів. Вона відображає такий стан фінансових ресурсів, за якого підприємство, вільно маневруючи коштами, здатне шляхом ефективного їхнього використання забезпечити безперебійний процес виробництва і реалізації продукції, а також витрати на його розширення і відновлення.

Аналізостанніхдослідженьіпублікацій.Дослідженням питань щодо поліпшення фрінансового забезпечення, а саме створення умов для фрінансово стійкої діяльності господарюючих суб'єктів, займалися багато вітчизняних і зарубіжних учених, усі свої дослідження вони висвітлили у наукових працях. Зокрема, це праці Е. Альтмана, І.О. Бланка, О.І. Барановського, Є.В. Мниха, О.В. Павловської, Н.О. Русак, В.А. Русак, Г.В. Савицької, В.К. Савчука, О.О. Терещенка, В.В. Чепурко, А.Д. Шеремета та інших учених.

У сучасній економічній літературі немає єдиного підходу до визначення поняття «фрінансова стійкість». Його трактувань досить багато. Вони зазвичай дублюють чи доповнюють одне одного. Ми вважаємо, це зумовлено історичним поступом економічної науки, змінами в економічних відносинах, що викликає появу та розвиток нових думок і понять.

Постановка завдання. Метою дослідження $€$ комплексний розгляд та аналіз поняття фрінансової стійкості підприємства. Основне завдання аналізу 
фрінансової стійкості полягає у визначенні спроможності підприємства протистояти негативній дії різних чинників (зовнішніх, внутрішніх та непередбачуваних), що впливають на його фрінансовий стан. Результатом такого аналізу повинен бути висновок щодо його спроможності здійснювати господарську діяльність, отримувати прибуток в умовах економічної самостійності, а також вірогідність збереження такого стану підприємства.

Виклад основного матеріалу дослідження. Підсумовуючи різні тлумачення суті фрінансової стійкості, можна стверджувати, що фрінансова стійкість - це узагальнювальна якісна оцінка фрінансового стану суб'єкта господарювання, яка відображає основні тенденції зміни фрінансових відносин під впливом найрізноманітніших чинників, як внутрішніх, так і зовнішніх, і виражається в кредитота платоспроможності підприємства, а також у постійному зростанні прибутку й капіталу за мінімального ризику [3, с. 15].

Фінансова стійкість відображає економічні відносини, які фрормують фрінансовий механізм забезпечення поступального руху соціально-економічного розвитку. Результати охарактеризованих визначень економічної категорії «фінансова стійкість» дали змогу з теоретичного погляду не лише визначити ії̈ сутність, а й обґрунтувати її основні складники та важливість позитивного впливу на результати фрункціонування підприємства.

Умовою і гарантією виживання й розвитку будь-якого підприємства як бізнес-процесу є його фрінансова стійкість. Якщо підприємство фрінансово стійке, то воно у змозі витримати несподівані зміни ринкової кон'юктури і не опинитися на краю банкрутства. Більше того, чим вище його стійкість, тим більше переваг перед іншими підприємствами того ж сектору економіки в одержанні кредитів і залученні інвестицій. Фінансово стійке підприємство вчасно розраховується за своїми обов'язаннями 3 державою, позабюджетними фондами, персоналом, контрагентами. Це сприяє його іміджу - головному складнику нематеріальних активів господарюючого суб'єкта [4, с. 115].

До основних чинників, що визначають фрінансову стійкість підприємства, належать фрінансова структура капіталу (співвідношення позикових і власних коштів, а також довгострокових і короткострокових джерел коштів) і політика фрінансування окремих складників активів (насамперед необоротних активів і запасів).

Для оцінки рівня фрінансової стійкості використовують такі показники:

- коефіцієнт співвідношення залучених і власних коштів;

- коефріцієнт автономії (платоспроможності);

- коефріцієнт маневреності власних коштів;

- коефіцієнт ефективності використання власних коштів;
- коефіцієнт використання фрінансових ресурсів усього майна.

Коефіцієнт співвідношення позикових і власних коштів характеризує структуру фрінансових ресурсів підприємства. Розраховується як частка від розподілу суми позикових коштів на суму власного капіталу. Максимально припустиме значення цього показника становить 1 (що припускає рівність позикових і власних коштів) [6, с. 64].

Коефіцієнт фрінансової автономії, або незалежності (коеоріцієнт концентрації власного капіталу), дає характеристику частці власних коштів (власного капіталу) у загальній авансованій сумі коштів. Підприємство є тим більш стабільним, незалежним та фрінансово стійким від зовнішніх кредиторів, чим більше значення цього показника. Уважається, що в підприємство з високою питомою вагою власного капіталу кредитори з більшим бажанням вкладають кошти, тому що воно має можливість погасити заборгованість за рахунок власних активів. На практиці доведено, що вся сума заборгованості повинна бути не більшою, ніж сума власних джерел фрінансування, тобто загальна сума капіталу має бути сорормована не менше ніж наполовину за власні кошти.

Тому задля максимізації припливу коштів підприємству слід розробляти ширше коло моделей договорів із постачальниками з гнучкими умовами оплати. Система знижок за прискорення оплати більш ефективна, ніж система штрафних санкцій за прострочену оплату. В умовах інфляяції це призводить до зменшення поточної вартості реалізованої продукції, тому слід точно оцінити можливість надання знижки за дострокової оплати [2, с. 99].

Коеріцієнт маневреності власних коштів характеризує ступінь мобільності використання власного капіталу. Коефіцієнт маневреності показує частку власних коштів, вкладених в оборотні активи. Чітких рекомендацій у значенні цього коефріцієнта немає, але вважається, що його значення повинно бути не менше 0,2, що дасть змогу забезпечити достатню гнучкість у використанні власного капіталу. Для оцінки коефіцієнта маневреності необхідно порівняти його значення з рівнем минулих періодів, середньогалузевим значенням або рівнем у найближчих конкурентів.

Коефіцієнт ефективності використання власних коштів показує, скільки прибутку дає 1 грн власних коштів. Теоретично нормальним значенням цього коефріцієнта $€$ значення не менше 0,4.

Коефіцієнт використання фрінансових ресурсів (усього майна) дає змогу визначити, за який період одержаний прибуток може компенсувати вартість майна. Нормативного числового значення для цього коефіцієнта немає, позитивним уважається збільшення цього коефріцієнта по відношенню до попереднього періоду. 
Кожному підприємству для поліпшення фрінансового стану потрібно стежити за наявністю вільних фрінансових коштів, співвідношенням дебіторської й кредиторської заборгованості, знаходити шляхи та способи, що дають змогу скоротити величину заборгованості на підприємстві [5, с. 205].

Визначивши фрінансову стійкість суб'єкта господарювання, слід звернути увагу на чинники, які впливають на її зниження або зростання, адже, визначивши причину зниження, можна правильно побудувати стратегію щодо забезпечення фрінансової стійкості підприємства. Отже, можна назвати такі основні внутріні чинники, які істотно впливають на фрінансову стійкість підприємства:

- належність підприємства до певної галузі;

- розмір сплаченого статутного капіталу;

- структура витрат, їх динаміка порівняно з прибутком;

- розмір фрінансових ресурсів, включаючи запаси й резерви.

Також вагомий вплив на підприємство і його фрінансову стійкість впливають еконономічні та політичні процеси в країні, технологічний розвиток, платоспроможність споживачів, конкуренція. Ці фрактори ми відносимо до зовнішніх чинників впливу [1, с. 58].

Поліпшення рівня фрінансової стійкості підприємства може відбутися лише за досягнення певних цілей:

- усунення неплатоспроможності підприємства;

- зміна фрінансової стратегії для прискорення економічного зростання;

- зниження обсягів споживання інвестиційних ресурсів підприємства у поточному періоді.

Слід відзначити, що найбільше темпи росту показників фрінансової стійкості залежать від рентабельності продажу, обіговості капіталу, фрінансової активності зі залучення коштів, норми розподілу прибутків на інвестиційні потреби [7, с. 208].

Висновки з проведеного дослідження. Отже, фрінансова стійкість відображає такий стан фрінансових ресурсів і такий ступінь їх використання, за якого підприємство здатне забезпечити безперебій- ний процес фрункціонування виробництва, а також затрати на його диверсиорікацію й модернізацію. А сам процес забезпечення фрінансової стійкості підприємства має бути спрямований на мінімізацію негативного впливу зовнішнього та внутрішнього середовища на діяльність підприємства.

\section{БІБЛІОГРАФІЧНИЙ СПИСОК:}

1. Базілінська О.Я. Фінансовий аналіз. Київ, 2009. $328 \mathrm{c}$

2. Фінансова діяльність підприємств : підручник / О.М. Бандурка та ін. Київ : Либідь, 1998. 125 с.

3. Головко Т.В. Методика аналізу фрінансової звітності підприємства. Київ : Компас, 2008. 32 с.

4. Економічний аналіз і діагностика стану сучасного підприємства / Т.Д. Костенко та ін. Київ, 2007. $400 \mathrm{c}$.

5. Кужельний М.В. Організація обліку : підручник. Київ : ЦНЛ, 2010. 352 с.

6. Шеремет А.Д., Сайфулин Р.С. Финансы предприятий. Москва : ИНФРА-М, 1998. 305 с.

7. Шеремет А.Д., Сайфрулин Р.С. Методика фринансового анализа. Москва : ИНФРА-М, 1996. 208 с.

\section{REFERENCES:}

1. Basilinskaya O.Y. (2009) Finansoviy analyz [Financial Analysis]. Kiev, pp. 328.

2. Bandurka O.M., Korobov N.L., Orlov P.I., Petrova K.L. (1998) Finansova dialnist pidpriemstv [Financial activity of enterprises]. Kiev: Lybid.

3. Golovko T.V. (2008) Metodika analizu finansovoi zvitnosti pidpriemstva [Methods of analysis of financial statements of an enterprise]. Kyiv: Compass.

4.Kostenko T.D., Podgora E.A., Ryzhikov V.S., Pankov V.A., Gerasimov A.A., Rovenskaya V.V. (2007) Economichniy analiz diagnostika stanu suchasnogo pidpriemstva [Economic analysis and diagnostics of the state of the modern enterprise].

5. Kuzhelny M.V. (2007) Organizatsia obliku [Organization of accounting]. Kyiv: CNL.

6. Sheremet A.D., Saifulin R.S. (1998) Finansi pidpriemstva [Business finance]. Moskva: INFRA-M.

7. Sheremet A.D., Saifulin R.S. (1998) Metodyka fnansovogo analizu [Methods of financial analysis] Moskva: INFRA-M. 
Starkina Mariana

Student

Yuriy Fedkovych Chernivtsi National University

Havatiuk Liudmila

Candidate of Economic Sciences,

Instructor at Department of Public, Corporate Finance and Financial Intermediation

Yuriy Fedkovych Chernivtsi National University

\section{FINANCIAL STABILITY OF THE ENTERPRISE AS THE MAIN INDICATOR OF FINANCIAL CONDITION}

Problem statement. In market conditions, financial stability serves as a pledge of survival and the basis of a stable condition of the financial assets enterprise. It reflects the state of financial resources, in which the enterprise, freely maneuvering the funds, is able, through their efficient use, to ensure a smooth process of production and selling of products, as well as the cost of its expansion and restoration.

Analysis of the labess research ance. Many domestic and foreign scientists have been studying the issues related to the improvement of financial support, namely the creation of conditions for financially sustainable activity of business entities, and have covered all their research in scientific works. In particular, these are the works of: E. Altman, I.A. Blanca, O.I. Baranovsky, E.V. Mnykh, O.V. Pavlovskaya, N.O. Rusak, V.A. Rusak, G.V. Savitskoy, V.K. Savchuk, O.O. Tereshchenko, V.V. Chepurko, A.D. Sheremet and other scientists.

There is no single approach in contemporary economic literature to the definition of "financial sustainability". There are many interpretations of it. They usually duplicate whether complement each other. We believe that this is due to the historical progress of economic science, changes in economic relations, and this leads to the emergence and development of new thoughts and concepts. The main objective of this article is to determine the essence of financial stability of the enterprise as the main indicator of financial condition.

Setting objectives. The purpose of the article is a comprehensive review and analysis of the concept of financial stability of the enterprise. The main task of the analysis of financial stability is to determine the ability of the company to withstand the negative effects of various factors (external, internal and unpredictable) that affect its financial condition. The result of such an analysis should be a conclusion as to its ability to carry on business, to profit in terms of economic independence, as well as the likelihood of maintaining such a state of the enterprise.

Presenting main material. Summarizing the different interpretations of the nature of financial stability, it can be argued that financial stability is a generalized qualitative assessment of a financial position of an entity that reflects the main trends of financial relations under the influence of various factors, both internal and external, and is expressed in credit and solvency of the enterprise, as well as in the constant growth of profit and capital with minimal risk.

Financial stability reflects the economic relations that form the financial mechanism for ensuring the sustained movement of socio-economic development. The results of the characterized definitions and economic category "financial stability" made it possible not only to determine its essence from a theoretical point of view, but also to substantiate its main components and the importance of a positive influence on the results of the enterprise.

The condition and guarantee of survival and development of any enterprise as a business process is its financial stability. If the company is financially sound, it is able to "withstand" unexpected changes in the market situation and not be on the verge of bankruptcy. Moreover, the higher its resilience, the greater the advantages over other enterprises in the same sector of the economy in obtaining loans and attracting investments. A financially sustainable enterprise is timely settled for its responsibilities with the state, extra-budgetary funds, staff, and counterparties. This contributes to its image, the main component of the intangible assets of the entity .

The main factors determining the financial sustainability of an enterprise include the financial structure of capital (the ratio of debt and equity, as well as long-term and short-term sources of funds) and the policy of financing individual components of assets (primarily non-current assets and stocks).

The following indicators are used to assess the level of financial soundness:

- ratio of attracted and own funds;

- coefficient of autonomy (solvency);

- coefficient of maneuverability of own funds;

- coefficient of efficiency of use of own funds;

- ratio of financial resources of all property.

Ratio of debt-to-equity ratiocharacterizes the structure of financial resources of the enterprise. It is calculated as a fraction of the distribution of the amount of borrowed funds in the amount of equity. The maximum permissible value of this indicator is 1 (assuming equality of borrowing and own funds) . 
The coefficient of financial autonomy, or independence (coefficient of concentration of equity), characterizes the share of own funds (equity) in the total advance amount of funds. The enterprise is more stable, independent and financially sound than external creditors, the greater the value of this indicator. It is believed that high-net-worth businesses are more willing to invest because they have the ability to repay debt from their own assets. In practice, it is proved that the total amount of debt should not be greater than the sum of own sources of financing, ie the total amount of capital should be formed not less than half at its own expense.

Therefore, in order to maximize the flow of money to the enterprise, a wider range of contract models should be developed with suppliers with flexible payment terms. A system of discounts for speeding up payment is more effective than a system of penalties for late payment. In the context of inflation, this leads to a decrease in the current value of sales, so the possibility of providing a discount with early payment should be carefully assessed .

The coefficient of maneuverability of own funds characterizes the degree of mobility of the use of equity. Maneuverability ratio shows the proportion of own funds invested in current assets. There are no clear recommendations on the value of this factor, but it is considered that its value should be at least 0.2 , which will provide sufficient flexibility in the use of equity. To evaluate the maneuverability factor, it is necessary to compare its value with the level of past periods, the industry average or the level of its closest competitors

The coefficient of efficiency of use of own funds shows how much profit 1 UAH gives. own funds. Theoretically, the normal value of this factor is at least 0.4 .

The ratio of use of financial resources (total assets) allows you to determine for what period the profit received can offset the value of the property. There is no normative numerical value for this coefficient, positive is the increase of this coefficient with respect to the previous period.

To improve the financial situation of each enterprise, it is necessary to monitor the availability of available financial resources, the ratio of receivables and payables, to find ways and ways that can reduce the amount of debt in the enterprise.

When determining the financial strength of an entity, consideration should be given to the factors that affect its decline or growth, since determining the cause of the decline can properly build a strategy to ensure the financial stability of the enterprise. Therefore, the following are the main internal factors that significantly affect the financial stability of the enterprise:

- affiliation of the enterprise to a certain branch;

- the amount of paid-up share capital;

- cost structure, their dynamics in comparison with profit;

- the size of financial resources, including reserves and reserves.

Economic and political processes in the country, technological development, consumer solvency, and competition also have a significant impact on the enterprise and its financial stability. We attributed these factors to external factors of influence.

Conclusion. Thus, financial stability reflects the state of financial resources and the degree of their use, in which the enterprise is able to ensure a smooth process of production, as well as the cost of its diversification and modernization. And the process of ensuring the financial stability of the enterprise should be aimed at minimizing the negative impact of the external and internal environment on the activity of the enterprise. 